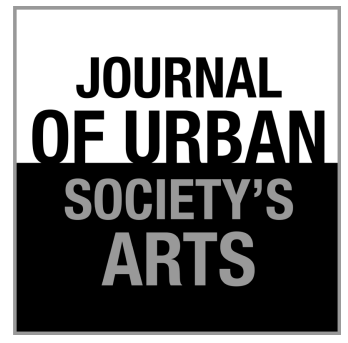

Volume 2 Nomor 1 , April 2015: 55-61

\section{Deformasi Wajah Karakter Kartun Berbasis Klaster Titik Fitur Gerak}

\author{
Samuel Gandang Gunanto, Matahari Bhakti Nendya, \\ Mochamad Hariadi, Eko Mulyanto Yuniarno \\ Program Studi Teknik Elektro Konsentrasi Teknologi Game, \\ Institut Teknologi Sepuluh November (ITS) Surabaya \\ E-mail: gandang6@gmail.com; HP: 08562543431
}

\begin{abstract}
ABSTRAK
Pendekatan tradisional animasi ekspresi wajah sangat tergantung pada animator dalam pembuatan gerakan kunci dan rangkaian gerakan ekspresi wajah.

Problematika yang sering dijumpai adalah penggunaan kerangka dan gerakan wajah yang sama untuk model yang berbeda membutuhkan waktu yang lama dikarenakan kompleksitas ekspresi wajah manusia. Pendekatan simulasi kulit wajah dan otot pada praktiknya masih memerlukan intervensi animator untuk pengaturan kulit wajah terhadap tulang/tengkorak kepala dan konfigurasi sambungan otot gerak di wajah. Hal ini menyebabkan produksi animasi wajah untuk satu wajah tidak dapat digunakan ulang secara langsung untuk wajah lainnya karena kekhususannya tersebut. Oleh karena itu, proses pengamatan perubahan bentuk ekspresi wajah dengan adanya area bobot pada model wajah 3D menggunakan pendekatan klaster di titik fitur gerak mempunyai peran penting untuk mengidentifikasi proses penyesuaian bentuk wajah yang berlainan dan variasi pengaruh gerakan pada wajah karakter kartun.
\end{abstract}

Kata kunci: deformasi wajah, klaster titik, karakter kartun

\begin{abstract}
Cartoon Character Face Deformation Based on Motion Feature-Point Cluster. The traditional approach animated facial expression is highly dependent on animator to create key of movement and continuity the motion of facial expressions. The problems frequently encountered is the use of the skeleton and the same facial movements for different models takes a long time because of the complexity on human facial expressions. Simulation approach to facial skin and muscles in practice still requires intervention animators to control the facial skin to bone/skull and connection configuration in facial muscle movement. This leads to the production of facial animation for one face can't be reused directly to the other face model because of their specialization. Therefore, the observation of deformation facial expressions with weights area on a $3 D$ face model using motion feature-point cluster approach have an important role to identify the adjustment process on different facial shapes, and variations of movement on cartoon character face.
\end{abstract}

Keywords: face deformation, point cluster, cartoon character 


\section{Pendahuluan}

Kelangkaan sumber daya animasi yang ada sekarang menjadi kendala utama jika dikehendaki percepatan dalam proses produksi animasi, khususnya dikarenakan proses pembuatan gerakan pada animasi saat ini masih banyak menggunakan teknik manual dengan mengandalkan pengubahan frame-by-frame. Hal ini akan banyak menyita waktu dan membutuhkan sumber daya manusia yang besar.

Pendekatan tradisional untuk menganimasikan ekspresi model wajah bergantung pada seorang seniman untuk menciptakan gerakan kunci dan kemudian menggabungkannya menjadi serangkaian gerakan ekspresi wajah. Game dengan aturan permainan yang interaktif membutuhkan animasi wajah dalam melakukan komunikasi atau interaksi dengan area permainannya. Sumber daya yang terbatas menjadikan animasi wajah dalam game sering ditiadakan. Pada masa sekarang ini dengan munculnya sistem permainan game yang diselingi film animasi di dalamnya menuntut keberadaan animasi ekpresi wajah yang mutlak ada untuk memberikan aspek hiburan dan cerita bagi si pemain. Problematika yang dijumpai bagi produsen adalah penggunaan kerangka dan gerakan wajah yang sama dalam model yang berbeda adalah tugas yang sangat menghabiskan waktu bagi para animator (Orvalho, Zacur, \& Susin, 2006:3). Problematika ini juga terjadi pada pembuatan gerakan animasi wajah dikarenakan penyesuaian gerakan yang alami dan detail diperlukan untuk membuat ekspresi wajah menjadi menarik dan membuat karakter menjadi lebih hidup. Oleh karena itu, pencarian sebuah solusi yang mampu menangani permasalahan itu menjadi prioritas utama untuk dikerjakan, terlebih yang mampu memunculkan sebuah desain teknologi tepat guna di sektor industri animasi.

Animasi wajah merupakan aspek penting di lingkungan virtual 3D yang menghadirkan keberadaan karakter, baik manusia maupun yang menyerupainya. Pemanfaatannya meliputi industri game 3D, perangkat lunak interaktif dan film animasi 3D. Dalam menghasilkan animasi wajah yang baik diperlukan waktu yang lama bagi

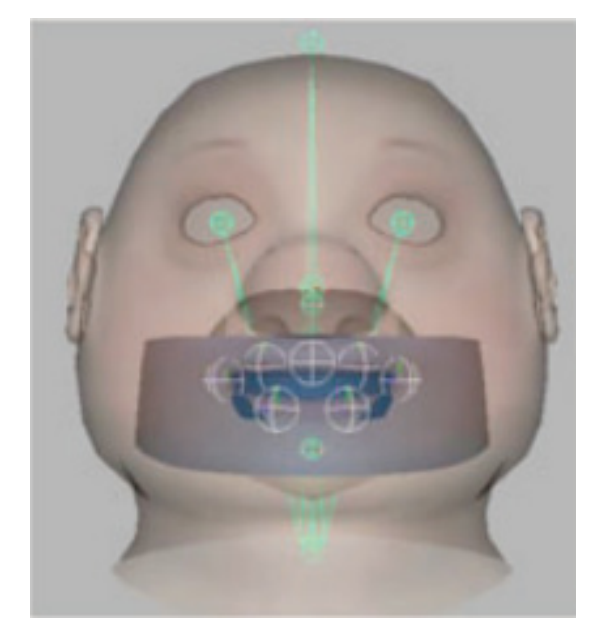

Gambar 1. Proses rigging wajah model 3D

(Orvalho, Zacur, \& Susin, 2008:6)

seorang animator ahli dikarenakan kompleksitas ekspresi wajah manusia yang merupakan bagian penting dalam pergerakan secara alamiah (Parke, 1972:453). Pada masa sekaamg ini menunjukkan bahwa perkembangan penelitian animasi wajah masih banyak dihasilkan terutama untuk dua aspek penting: proses rigging wajah dan pemindahan ekspresi antardua buah karakter virtual 3D atau antarmanusia ke karakter 3D seperti yang ditunjukkan pada gambar 1 .

Proses rigging membutuhkan waktu pengerjaan manual yang lama bagi seniman. Melalui metode sederhana seperti shape-blending, seorang seniman perlu membuat sebuah bentuk acuannya. Pendekatan teknik skinning secara umum memerlukan pendefinisian manual tentang persendian yang memengaruhi pergerakan pada wajah, seperti pada alis, dahi, pipi/rahang, dan mulut. Animasi wajah apabila menggunakan pendekatan simulasi kulit wajah dan otot maka intervensi seniman selaku animator terdapat pada pengaturan kulit wajah terhadap tulang/tengkorak kepala dan konfigu-rasi sambungan-sambungan otot gerak di wajah. Hal inilah yang menyebabkan produksi animasi wajah untuk satu wajah tidak dapat digunakan ulang secara langsung untuk wajah lainnya karena kompleksitas dan kekhususannya tersebut.

Aspek penelitian yang kedua di bidang animasi wajah adalah mengenai ide produksi animasi wajah yang alamiah dengan melakukan pemindahan gerak dari satu wajah ke wajah karakter yang baru. 


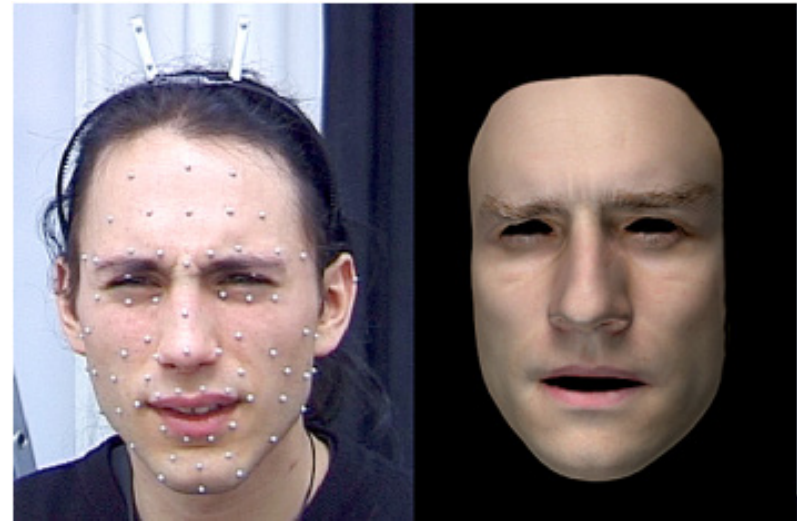

Gambar 2. Transfer gerakan wajah menggunakan fitur titik (Curio, et al., 2006:5)

Hal ini dapat dilakukan dengan cara panduan gerak tangkapan kamera video 2D dari aktor manusia secara langsung ataupun dengan pemindahan gerak dari karakter virtual yang telah ada. Cara kedua ini memiliki manajemen memori yang baik sehingga sering digunakan untuk produksi animasi di industri game. Proses penyimpanan gerak dilakukan dengan menyimpan satu buah informasi gerak untuk gerakan yang sama. Keuntungan yang di dapat melalui teknik ini menunjukkan kesulitan yang dijumpai juga cukup besar yaitu proses pembuatan model target animasi yang diupayakan menyerupai aktor aslinya supaya dapat optimal menangkap detail ekspresi wajah sang aktor khususnya titik-titik wajah yang memengaruhi ekspresi. Hal tersebut menyebabkan diperlukannya sebuah teknik pemindahan ekspresi yang mampu mengadaptasi perubahan sumber/aktor dan perubahan bentuk morfologi model targetnya. Penggambarannya dapat dilihat pada gambar 2 .

Pemanfaatan teknologi visi komputer sudah ada di berbagai bidang ilmu, salah satunya yang sedang berkembang saat ini adalah pengembangan di ranah ilmu seni kreatif digital, seperti animasi dan game. Di bidang ini, teknologi visi komputer berperan di area produksi (Perales, 2002:3). Waktu produksi yang pada umumnya memakan waktu lama dapat dipersingkat secara signifikan.

Teknologi visi komputer yang berperan penting di bidang animasi dan game sebagai pengatur gerak model virtual adalah penangkapan gerak manusia atau human motion capture. Teknologi ini mengadopsi indera mata manusia untuk mengenali fenomena tangkapan kamera. Gerakan manusia yang ditangkap dapat dipetakan ke dalam sebuah model figur kerangka gerak. Hal ini juga berlaku bagi gerakan pada wajah dengan mengandalkan fitur penanda. Letak fitur penanda ditempatkan pada sendi gerak wajah dan otot yang memiliki pergerakan signifikan dalam perubahan ekspresi. Hal ini digunakan supaya penangkapan gerak pada wajah dapat optimal sehingga pemetaannya nanti pada model virtual dapat menyerupai aslinya. Prinsip utama dari penangkapan gerak manusia adalah pembangkitan animasi gerak model 3D oleh model manusia sesungguhnya melalui penangkapan kamera (Aggarwal \& Cai, 1999:428). Kehandalan sistem ini ditentukan oleh ketepatan estimasi dari pose model sehingga penentuan tiap segmen tubuh manusia di tahapan awal merupakan kunci keberhasilannya. Semakin akurat proses deteksi obyeknya, makin handal sistem yang dibangun (Perales, 2002:7; Moeslund, 1999:4).

Pemanfaatan teknologi ini sudah digunakan secara industri di bidang animasi dan game. Keterlibatannya berperan dalam sektor produksi dan bahkan juga dimanfaatkan sebagai antarmuka dengan pengguna atau pemain. Mahalnya implementasi dan operasional dalam sektor produksi (Shipley \& Brumberg, 2005:16; Perales, 2002:4) menjadikan teknologi ini jarang digunakan dan tidak dipunyai oleh studio-studio animasi di Indonesia yang tergolong masih dalam kriteria studio kecil.

Metode pembuatan ekspresi wajah 3D secara prinsip ada dua yaitu dengan penggunaan data hasil pemindai 3D atau hasil dari pahatan seniman (Faigin, 2008:37; Joshi, Tien, Desbrun, \& Pighin, 2003:187). Pada pembuatan animasi menggunakan blend-shapes bahwa setiap bentuk ekpresi wajah membutuhkan kesamaan geometri model wajah pada posisi netral. Hal ini membutuhkan waktu 2-3 minggu dan lebih dari 100 shapes dibuat untuk mewujudkan ekpresi wajah dan fonem dari sebuah karakter yang kompleks. Hal ini dapat diatasi dengan melakukan transfer otomatis bentuk dari model sumber ke model target yang dikehendaki (Orvalho, Zacur, \& Susin, 2008:11).

Ekspresi wajah manusia terbentuk dari adanya kontraksi otot wajah. Kulit berubah bentuknya dari kondisi awal dikarenakan adanya perubahan bentuk otot dan pergerakan tulang. Di dalam 
menghidupkan ekspresi karakter virtual merupakan tantangan yang besar karena wajah mampu menghasilkan sekitar 5000 ekspresi. Karakter seperti Shrek, film animasi tahun 2001, memiliki lebih dari 500 perintah yang diatur oleh fitur wajah. Dick Walsh menjelaskan bahwa untuk alis kanan ada kondisi dinaikkan, marah, sedih dengan setidaknya 15 kemungkinan perintah untuk mengaktifkan alis dan bagian lain dari wajah yang harus bergerak untuk menghasilkan ekspresi yang meyakinkan (Orvalho, Zacur, \& Susin, 2008:8).

Dibandingkan dengan perkembangan animasi gerak tubuh yang telah lebih dahulu berkembang sebetulnya penelitian di bidang animasi gerak wajah masih memerlukan banyak penyempurnaan. Saat ini pengendalian animasi gerak wajah masih tergantung pada keahlian pengolahan manual animator atau hasil peniruan aksi aktor yang sesungguhnya. Facial Action Coding System atau FACS (Ekman \& Friesen, 1978:73) merupakan sistem yang berguna untuk membantu melakukan analisis dan simulasi ekspresi gerak wajah serealistik mungkin, namun hal ini masih kurang dalam menggambarkan ekspresi wajah karakter animasi yang seharusnya seperti layaknya karakter kartun. Salah satu contoh penerapan FACS pada produksi animasi ekspresi wajah dapat dilihat pada gambar 3 .

\section{Metode Penelitian}

Proses pengumpulan landasan teori dan kajian pustaka dilakukan dengan metode studi pustaka, baik dari artikel jurnal, buku, maupun internet. Ide-ide yang didapatkan kemudian dilakukan pengeskploran dengan beragam pertimbangan baik dari segi waktu penelitian maupun biaya implementasi. Hasil yang diharapkan nantinya berupa hasil uji coba dari sebuah hipotesis yang telah teruji dan mempunyai nilai tepat guna bagi masyarakat Indonesia. Penelitian pendahuluan juga dilakukan melalui pengujian-pengujian eksperimentatif mendasar tentang perkiraan capaian yang dimungkinkan.

Secara umum proses penelitian dan pencapaian hasil akhir akan dilakukan dengan metode yang sama seperti di atas yaitu metode penelitian eksploratif eksperimentatif. Data yang dipakai adalah data gerak model wajah 3D yang ditangkap dengan alat sensor kamera motion capture pada area wajah. Diagram alir percobaan yang dilakukan dapat dilihat pada gambar 4.

Proses awal pengerjaan diawali dengan pendefinisian tulang gerak atau sering disebut dengan proses rigging pada model karakter kartun 3D yang akan menjadi objek pengamatan. Tahap berikutnya adalah pembuatan area bobot gerak yang disesuaikan dengan banyaknya titik fitur gerak sehingga setiap titik fitur gerak mempunyai klaster yang berisi titik-titik tetangga yang masih terpengaruh oleh pusat titik fitur gerak tersebut.

Pengujian gerak dengan pendekatan manual bisa dilakukan setelah semua area bobot terbentuk dalam klaster-klaster. Pengujian gerak dengan pendekatan data motion capture baru bisa dilakukan
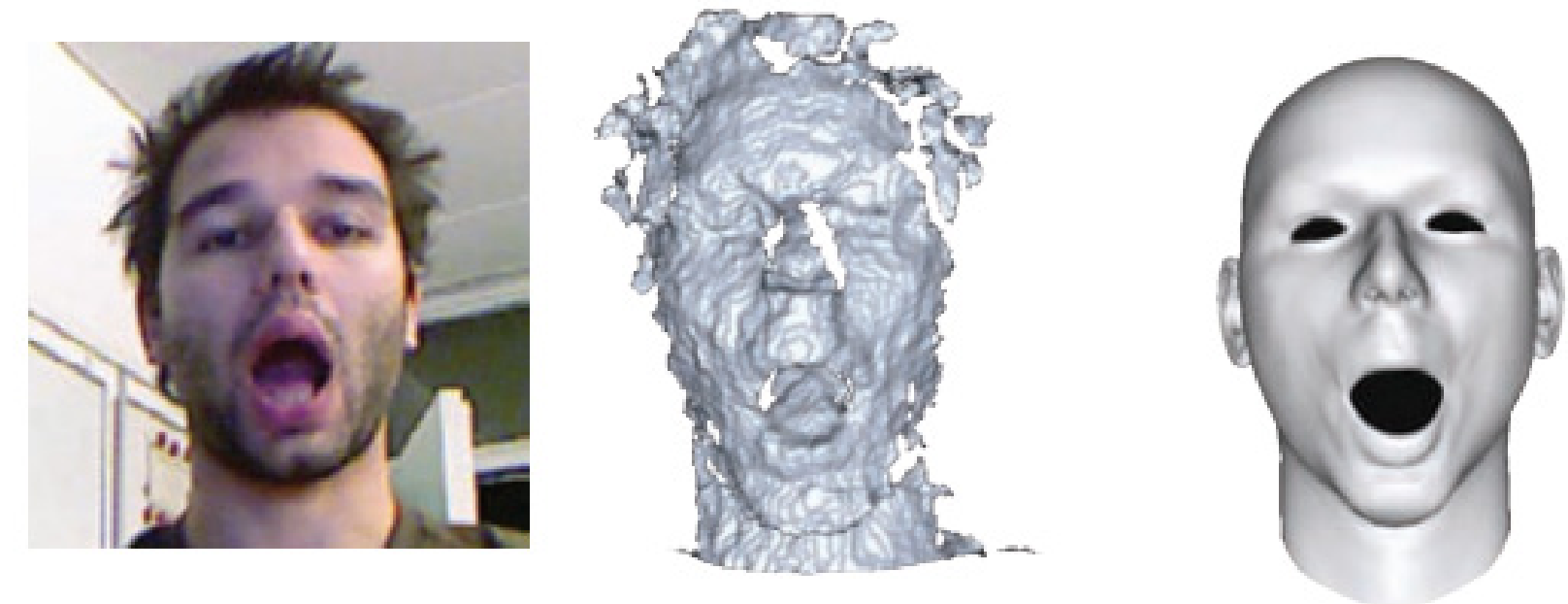

Gambar 3. Implementasi action unit FACS pada produksi animasi ekspresi wajah 3D

(Weise, Bouaziz, Li, \& Pauly, 2011:7) 


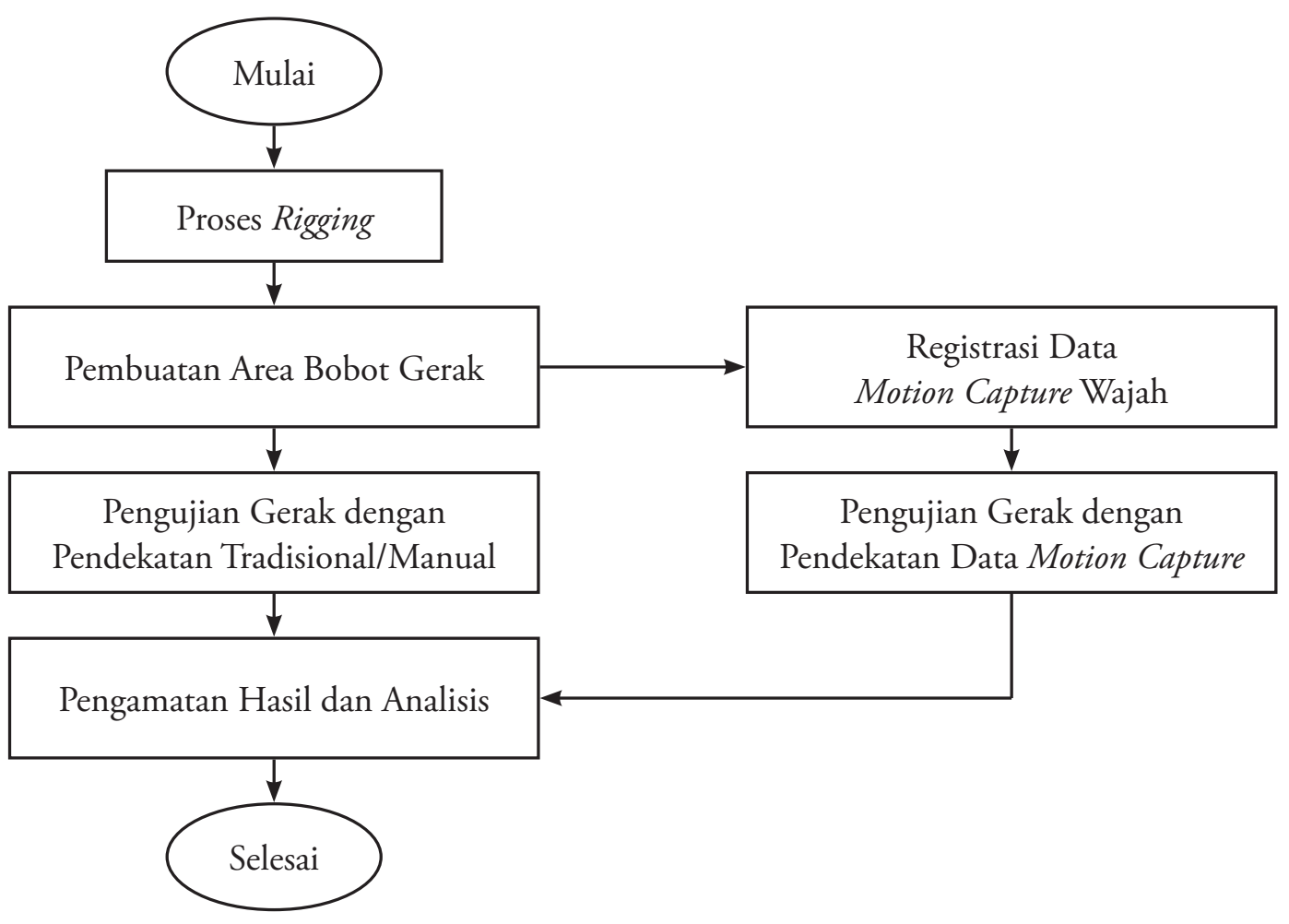

Gambar 4. Diagram Alir Percobaan

setelah dilakukan registrasi data motion capture wajah pada model wajah karakter kartun. Proses registrasi ini dilakukan dengan menyamakan asosiasi penamaan tulang gerak yang terdapat pada rigging wajah model dengan rekaman data motion capture. Setelah semua data sudah teregistrasi, proses pengujian dengan pendekatan data motion capture dapat dilakukan.

Pengamatan hasil dan analisis data tangkapan visual dilakukan dengan pembandingan hasil uji coba menggunakan pendekatan tradisional dan hasil uji coba menggunakan pendekatan data motion capture wajah. Hasil tersebut kemudian dijabarkan secara nyata dan dilakukan pembuatan kesimpulan atas hasil pengujian yang dilakukan.

\section{Hasil Penelitian}

Pada percobaan ini digunakan data motion capture menggunakan sistem dari optitrack. Pertama-tama data diambil dengan susunan titik fitur wajah sebanyak 31 marker seperti tampak pada gambar 5 . Semakin banyak data yang diambil, semakin detail perubahan terjadi, namun hal ini akan memberatkan proses komputasi. Data tersebut kemudian diterapkan pada model yang telah diberi rigging secara manual seperti tampak pada gambar 6.

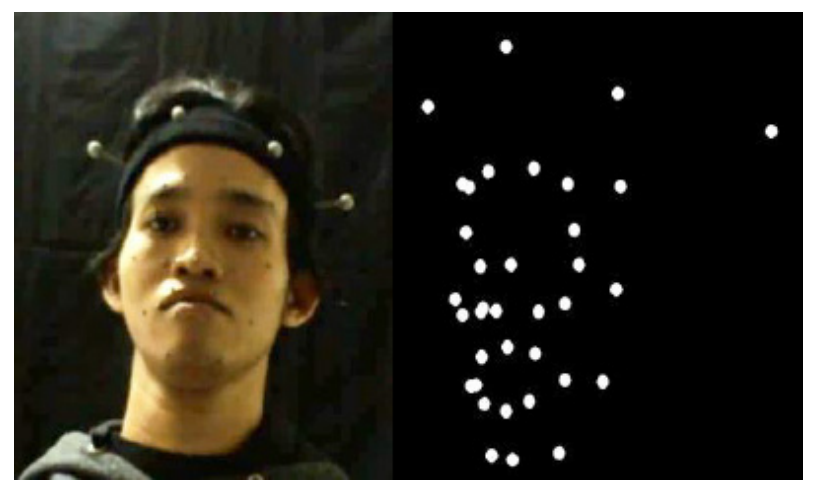

Gambar 5. Pengambilan data motion capture sebanyak 31 marker

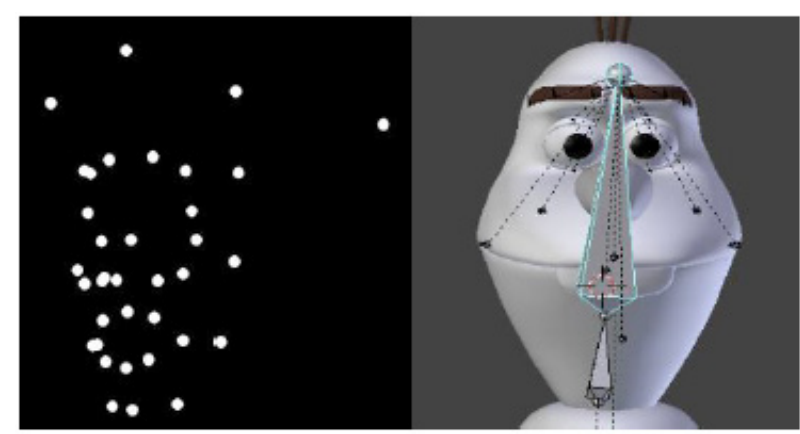

Gambar 6. Rigging yang telah diberi data motion capture 


\begin{tabular}{|c|c|c|c|}
\hline & \multicolumn{3}{|c|}{ Posisi Awal Penanda $f=0$} \\
\hline & Penanda 5 & Penanda 11 & Penanda 12 \\
\hline $\mathrm{X} 0$ & -2.39763 & -2.76825 & -2.55158 \\
\hline Y0 & -1.65183 & -1.42262 & -1.54503 \\
\hline $\mathrm{Z} 0$ & 3.72038 & 3.61477 & 3.50988 \\
\hline \multicolumn{4}{|c|}{ Posisi Penanda Pada Frame $f=45$} \\
\hline $\mathrm{Xf}$ & -2.38243 & -2.75308 & -2.53871 \\
\hline Yf & -1.64942 & -1.41935 & -1.54626 \\
\hline $\mathrm{Zf}$ & 3.70639 & 3.60657 & 3.51167 \\
\hline \multicolumn{4}{|c|}{ Perubahan Posisi Penanda $(d f)$} \\
\hline$d \mathrm{X}$ & 3.380029929 & 3.90418462 & 3.599390082 \\
\hline$d \mathrm{Y}$ & 2.334336883 & 2.009577589 & 2.185872295 \\
\hline$d \mathrm{Z}$ & 5.251528747 & 5.106261775 & 4.964985781 \\
\hline
\end{tabular}

Tabel 1. Data contoh penanda pada posisi 5, 11, dan $12 \mathrm{di}$ frame o dan frame 45 berikut nilai jaraknya

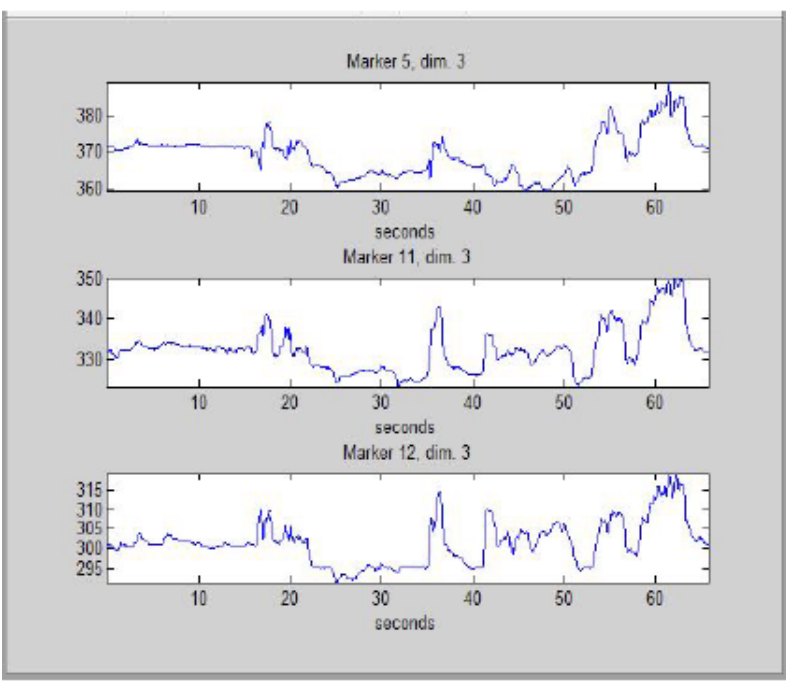

Gambar 7. Grafik jarak pergerakan fitur penanda 5, 11, dan 12 dari frame 0

Hasil dari implementasi data motion capture kemudian didata dan dihitung nilai jarak perubahan setiap titik fitur antar-frame sekaligus dijejaki dan diberi parameter. Contoh perubahan titik fitur penanda 5, 11, dan 12 dapat dilihat pada tabel 1, sedangkan grafik jarak pergerakannya dari frame 0 pada gambar 7 .

Pada percobaan tentang fungsi bobot yang diterapkan pada area klaster, pertama-tama perlu disiapkan model karakter kartun yang akan menjadi objek penelitian. Lalu dibuatlah rigging tulang wajah secara manual yang bersesuaian dengan bentuk wajah karakter Guido seperti tampak pada gambar 8 .
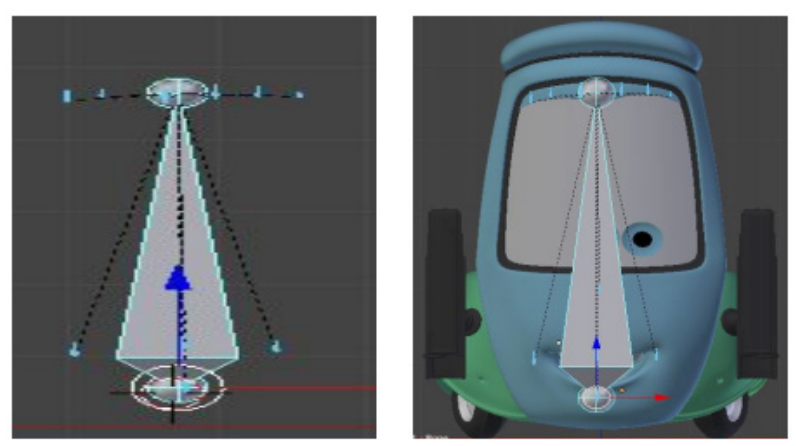

Gambar 8. Pembuatan rigging penulangan pada wajah karakter Guido
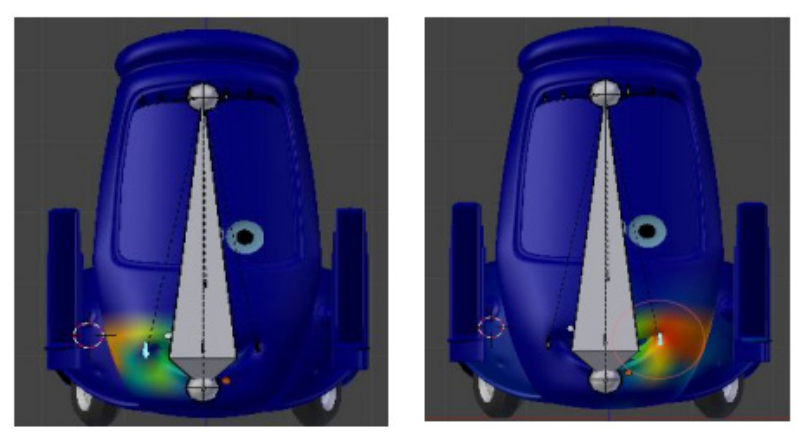

Gambar 9. Area klaster bobot bagian mulut kanan dan mulut kiri karakter Guido
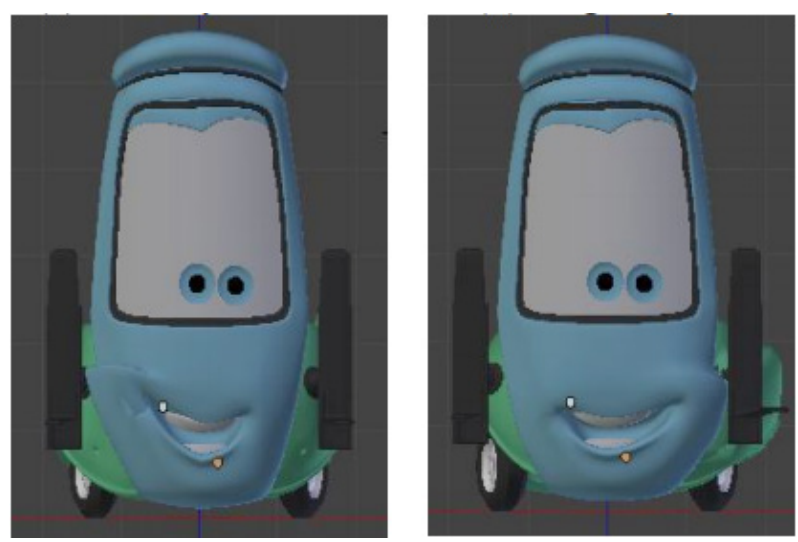

Gambar 10. Pembangkitan gerak secara manual frameby-frame di fitur titik wajah
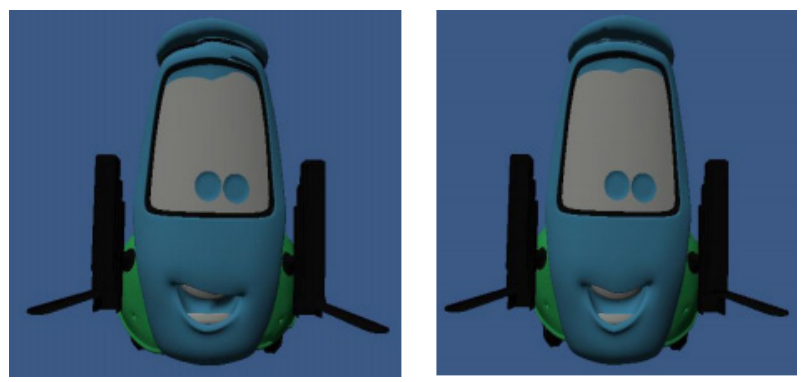

Gambar 11. Pembangkitan gerak menggunakan data motion capture di fitur titik wajah 
Setelah model diberi rigging pergerakan, dibuatlah area klaster bobot dengan pusat pada titik fitur gerak. Sebagai contoh pada Gambar 9 adalah area klaster pada bagian mulut kanan dan mulut kiri karakter Guido. Area inilah yang secara variasi akan mengalami perubahan yang dibangkitkan dari perubahan titik fitur gerak pada bagian mulut.

Pembangkitan pergerakan pada mulut dilakukan secara manual frame-by-frame maka didapatkan hasil seperti tampak pada Gambar 10. Gambar 11 merupakan hasil pergerakan yang didapat dengan implementasi data motion capture wajah. Tampak hasil data pergerakan animasi wajah menggunakan data motion capture yang diterapkan pada area klaster bobot lebih baik daripada data pergerakan secara manual.

\section{Simpulan}

Rigging wajah untuk karakter 3D mudah digunakan. Proses ini linier dan tidak memperberat perhitungan komputasi. Tulang wajah yang berasosiasi dengan titik fitur wajah dan area bobot dapat dikendalikan baik secara manual maupun otomatis. Data motion capture digunakan sebagai data komparasi terhadap pengubahan data manual. Pengaruh area bobot terhadap masing-masing pengubahan gerak sama besar. Perbedaannya terdapat pada hasil secara pengamatan visual dan kenaturalan ekspresi wajah akibat dari dua perlakuan itu. Tampak dengan kondisi awal yang sama, penggunaan data motion capture dapat menghasilkan gerak ekspresi wajah yang lebih baik dibandingkan secara manual.

\section{Ucapan Terima Kasih}

Peneliti mengucapkan terima kasih kepada Direktur DP2M Dikti Kementrian Pendidikan dan Kebudayaan RI yang telah memberi dana Hibah Doktor tahun 2013 yang memungkinkan terlaksananya program penelitian ini.

\section{Kepustakaan}

Aggarwal, J.K. dan Q. Cai. 1999. "Human Motion Analysis: A review." Computer Vision and
Image Understanding, Vol. 73 No. 3: 428-440. Curio, Cristobal, et al. 2006. "Semantic 3D Motion Retargeting for Facial Animation." Proc. of the 3rd Symposium on Applied Perception in Graphics and Visualization.

Ekman, P. dan W. V. Friesen. 1978. Facial Action Coding System: A Technique for the Measurement of Facial Movement. Palo Alto: Consulting Psychologists Press.

Faigin, Gary. 2008. The artist's complete guide to facial expressions 2nd Edition. New York: Watson-Guptill Publications.

Joshi, Pushkar, et al. 2003. "Learning controls for blend shape based realistic facial animation." Eurographics/SIGGRAPH Symposium on Computer Animation. ACM Press. 187-192.

Moeslund, T.B. 1999. "The Analysis-by-Synthesis Approach in Human Motion Capture: A Review." The 8th Danish conference on pattern recognition and image analysis. Denmark: Copenhagen University.

Orvalho, V. Costa, E. Zacur dan A. Susin. 2006. "Transferring Facial Expressions to Different Face Models." Ibero-American Symposium on Computer Graphics - SIACG (2006). The Eurographics Association.

Orvalho, Veronica C., Ernesto Zacur dan A. Susin. 2008. "Transferring the Rig and Animations from a Character to Different Face Models." COMPUTER GRAPHICS FORUM, Volume 27, Number 8: 1997-2012.

Parke, F.I. 1972. "Computer Generated Animation of Face." Proceedings of the ACM annual conference. ACM. 451-457.

Perales, F.J. 2002. "Human Motion Analysis \& Synthesis using Computer Vision and Graphics Techniques: State of Art and Applications." Workshop on Centre of Computer Graphics and Data Visualisation. Czech Republic: University of West Bohemia.

Shipley, T. F. dan J. S. Brumberg. 2005. Markerless Motion-capture for Point-light Displays. Philadelphia: Biological Motion Project, Department of Psychology, Temple University. Weise, Thibaut, et al. 2011. "Realtime PerformanceBased Facial Animation." Journal ACM Transactions on Graphics. 